\title{
Bioarchaeological investigation of sharp force injuries to the ribs and lower leg from the battle of Stoney Creek in the War of 1812
}

\author{
Laura LOCKAU $^{1 *}$, Ana-Maria DragOMIR ${ }^{1}$, Rebecca GILMOUR ${ }^{1}$, Madeleine MANT ${ }^{1}$, Megan BrICKLEY $^{1}$ \\ ${ }^{1}$ Department of Anthropology, McMaster University, Hamilton, Ontario, Canada
}

Received 6 May 2013; accepted 13 September 2013

\begin{abstract}
Sharp force trauma to the skeleton is an important source of evidence for violent injury in the past. Lesions attributable to possible perimortem sharp force injury were observed in 20 fragments within disarticulated and commingled human bone from the Smith's Knoll collection, an assemblage associated with the battle of Stoney Creek (1813, southern Ontario, Canada). Following analysis, questions remained surrounding lesions on fragments of the ribs and one distal fibula (SK0129). To better evaluate which injuries to the ribs were perimortem and what weapon is likely to have caused the injury to the fibula, faunal proxies were constructed and experimental lesions created using period replicas of a sword and a triangular socket bayonet. Similarities between the archaeological rib lesions and experimentally produced bayonet injuries indicate that 14 of the 38 lesions present in the rib fragments likely represent perimortem injuries. Two possible scenarios involving the sword and triangular socket bayonet were tested to determine the likely cause of the injury on the fibula. This injury displayed significant differences in appearance from the experimentally produced bayonet lesions on the replica lower leg, and was observed to correspond closely with characteristics associated with sword injuries described in the literature. This indicates that the lesion more likely represents the result of a sword stroke. Consideration of these injuries in the context of historical documentation regarding soldier experience during the battle of Stoney Creek helps to explain the apparently unusual placement of sharp force injuries within the skeleton of the individuals in the Smith's Knoll collection. This sample provides a unique opportunity for an evaluation of archaeological lesions that incorporates historical, experimental, and osteoarchaeological evidence, allowing a more nuanced understanding of violent injury in the past.
\end{abstract}

Key words: paleopathology, sharp force trauma, War of 1812, bayonet injuries, sword injuries

\section{Introduction}

Skeletal paleopathology provides researchers with access to valuable information regarding disease and injury experience in past populations (Ortner, 2011). Evidence of traumatic injury is often cited as one of the most prevalent lesions encountered in archaeological skeletal samples (Lovell, 2008). Investigation of the skeletal evidence for traumatic injuries takes on particular importance for samples connected with historically documented military contexts. The Smith's Knoll collection, associated with the Battle of Stoney Creek in the War of 1812, is an example of such an assemblage. Battlefields are an important area of focus for the examination of violence in the past; these sites provide an opportunity for archaeologists and bioarchaeologists to assess contextual aspects of historical warfare (Scott and McFeaters, 2011).

The Smith's Knoll assemblage consists of the fragmented,

* Correspondence to: Laura Lockau, Department of Anthropology, McMaster University, Hamilton, Ontario, Canada.

E-mail: lockaulm@mcmaster.ca

Published online 29 November 2013

in J-STAGE (www.jstage.jst.go.jp) DOI: 10.1537/ase.130913 disarticulated, and commingled remains of soldiers killed in the battle of Stoney Creek in southern Ontario, Canada (Figure 1) during the War of 1812 (1812-1814). This battle occurred in the pre-dawn hours of June 6,1813 as part of the American advance into Upper Canada. The British army, pursued by the Americans into the Niagara Peninsula, took advantage of American complacency and expectation of an easy victory to mount a night raid on the poorly organized American encampment in Stoney Creek (Elliott, 2009). Under cover of darkness, a relatively small contingent of 704 British soldiers ambushed an American force of around 3400 men (Elliott, 2009); primary accounts indicate that the ensuing battle was chaotic and disordered, with the troops in close contact with one another (Fredriksen, 1984, 1989; Merritt and Sutherland, 2001). Despite roughly equal losses, confusion within the American leadership caused the American forces to retreat, resulting in a major strategic victory for the British army (Elliott, 2009; Turner, 2000).

Following the battle of Stoney Creek, the dead from both armies were buried by British soldiers and local civilians in a local churchyard and in a mass grave on the battlefield. The Smith's Knoll collection contains only the individuals buried in the mass grave. The exact number of soldiers killed during the battle, as well as which or how many of them 


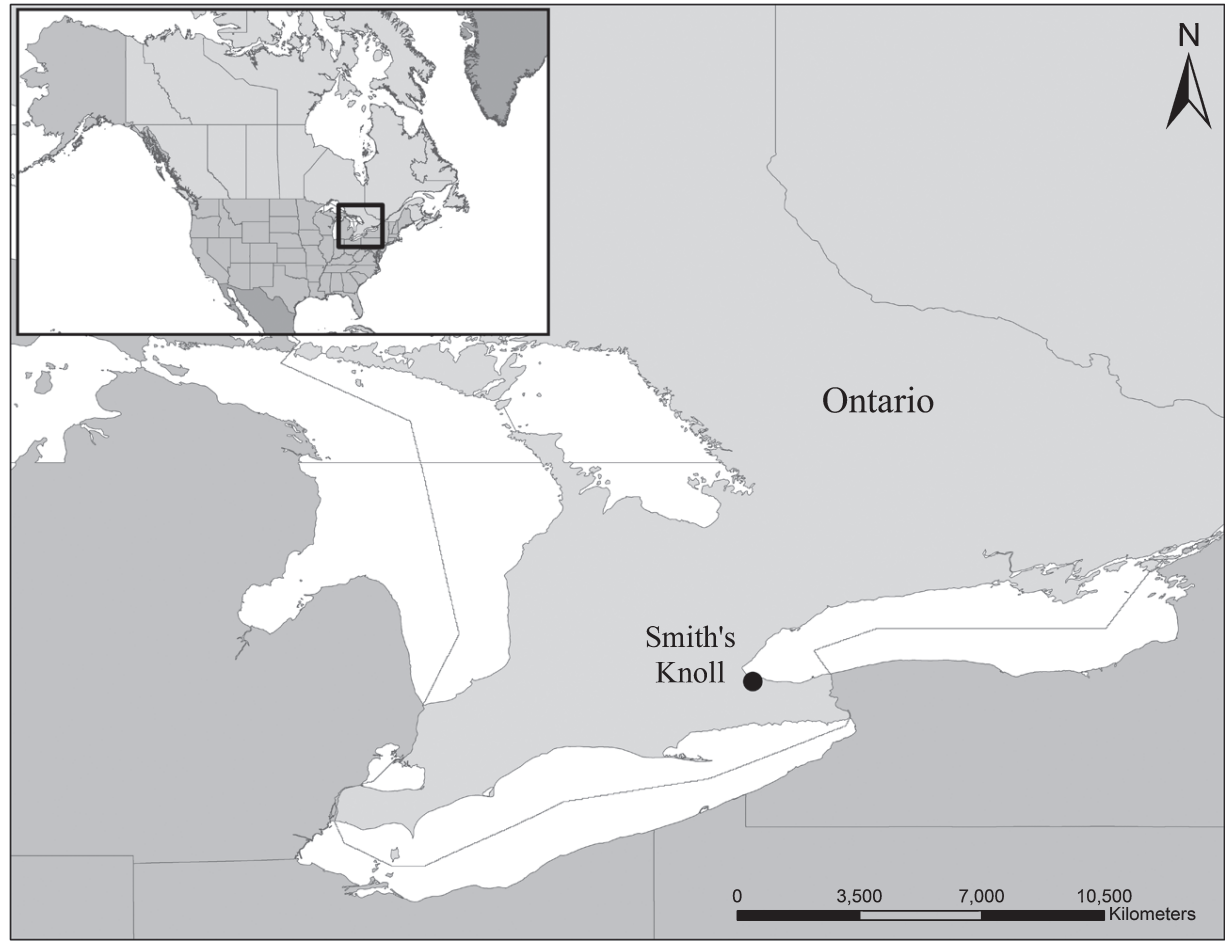

Figure 1. Map of southern Ontario and the Great Lakes region, showing the location of the Smith's Knoll site.

were buried in the mass grave, are unclear based on the records available. The official figure for the number of British casualties, cited relatively consistently in accounts of the battle, is 23 (Elliott, 2009). However, the number of American soldiers killed is not certain. While official accounts suggest that only 17 were killed, eyewitness accounts suggest that there were as many as 61 dead from both sides (Elliott, 2009). These numbers may have been manipulated in official accounts for many reasons, including attempts to present the battle in a more positive light to American authorities and thus protect the reputations of those in charge.

During the battle of Stoney Creek the opposing troops were in unusually close proximity to one another, and fighting primarily involved close-range and hand-to-hand combat that runs counter to the typical battle strategy for the period as described in the historical literature. Contemporary battle strategy was dictated by the main weapon, the flintlock smoothbore musket, which performed best in movements of massed infantry formations (Kaufman, 2003). Typical battles at this time provided little opportunity for the use of close-range bladed weapons such as the sword and bayonet. The model of cavalry sword most likely to have been used during this battle (Figure 2) was most effectively used to strike in a slashing motion. While the sword was likely only carried by officers, all soldiers carried bayonets affixed to the end of their muskets. This weapon was designed for use in a thrusting or stabbing motion in order to protect infantrymen at close range in defensive situations. Bayonets were also occasionally used offensively, mainly in the form of a bayonet charge after several rounds of musket fire. In such cases, the moral effect of a mass of infantry

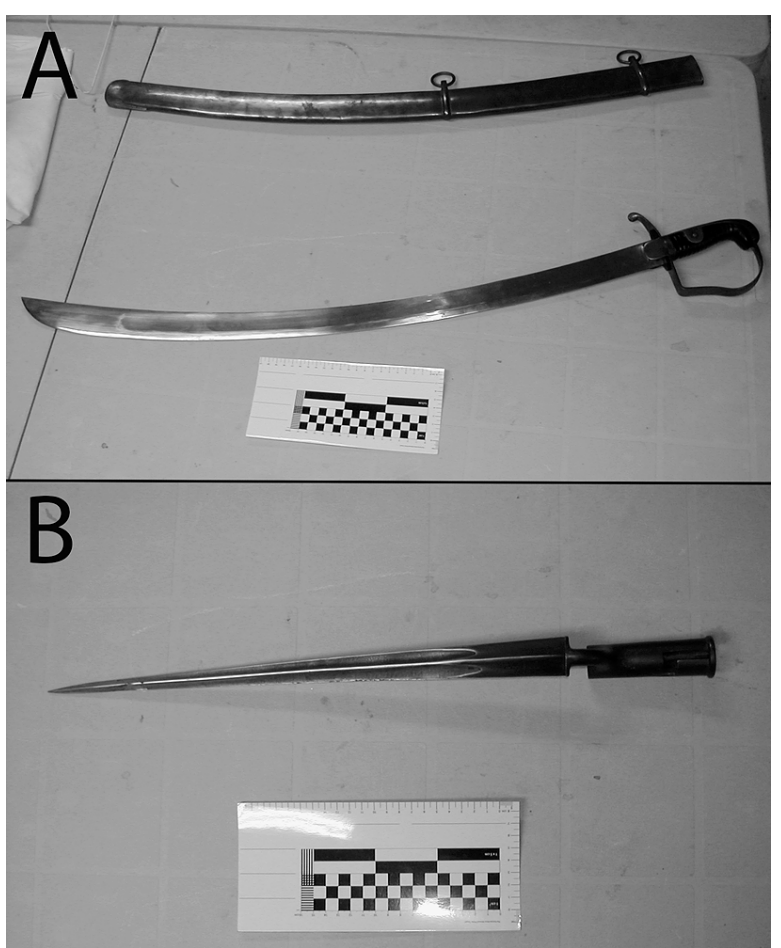

Figure 2. Replica weapons used during the experiment: (A) a replica of the model of cavalry sword commonly used during the War of 1812 , and (B) a replica of the triangular socket bayonet in use during this period. 
rushing forward with bayonets pointed was typically sufficient to intimidate the enemy and cause a retreat (Kaufman, 2003). Hand-to-hand fighting was therefore not particularly common and in a typical battle soldiers would not have much occasion to use their bayonet, nor officers to use their sword.

Sharp force trauma results from injury with a bladed weapon, such as a knife, hatchet, sword, or bayonet. These injuries typically manifest in bone as straight, incised lesions with very sharp edges. The characteristics of the lesion produced will differ based on the weapon involved, as well as how this weapon is used and the specific area of the blade that contacts the bone (Lewis, 2008; Smith et al., 2009). In the creation of sharp force lesions the proportion of blunt and sharp force is determined by the weight of the weapon, the sharpness of the blade, blade shape, and the direction of the force. The balance between blunt and sharp force contributes to lesion appearance and characteristics. For example, heavier hacking weapons such as an axe or hatchet will result in trauma with a higher blunt force component, producing a lesion that has more blunt characteristics than those caused by lighter and thinner slicing weapons such knives (Humphrey and Hutchinson, 2001). Lesions caused by the same weapon but inflicted using a different type of action will also differ in appearance, such as knife injuries resulting from slicing versus stabbing motions (Lewis, 2008). Such characteristics have been useful in differentiating between lesions produced by bladed weapons that differ significantly in weight, sharpness, and blade shape (Lewis, 2008). Many forensic and archaeological studies have experimentally investigated lesion characteristics associated with various types of sharp force trauma in the skeleton (e.g. Novak, 2000; Humphrey and Hutchison, 2001; Alunni-Perret et al., 2005, 2010; Lynn and Fairgrieve, 2009; Shaw et al., 2011). However, much of this experimental work has focused on axes, hatchets, and knives. While some research has involved skeletal injuries associated with swords (Lewis, 2008), no publications have addressed the experimental injury characteristics of the triangular socket bayonet, and to date no bayonet injuries have been reported in archaeological bone. Bayonets have a long, relatively flat, triangular blade, sharpened at both edges (Figure 2), which would be expected to produce wounds with a characteristic V-shaped profile differing in size based on the depth of penetration.

Contemporary accounts of the battle of Stoney Creek indicate that the cavalry sword and triangular socket bayonet would have played an important role during this battle (Fredriksen, 1984, 1989; Merritt and Sutherland, 2001). However, such accounts focus on the general battle conditions rather than the specifics of the injuries inflicted. Sharp force lesions with clear perimortem characteristics were observed in six fragments of long bone and small irregular bones within the Smith's Knoll collection, and 38 potential lesions were also observed in fragments of rib. Perimortem fractures were observed in one rib and one scapula, and firearm injuries were observed in three innominates, one scapula, and cranial elements (Lockau, 2012). Relatively straightforward sharp force lesions were observed in a femur, an ulna, a scaphoid, a patella, and a thoracic vertebra. Important questions remained linked to sharp force injuries

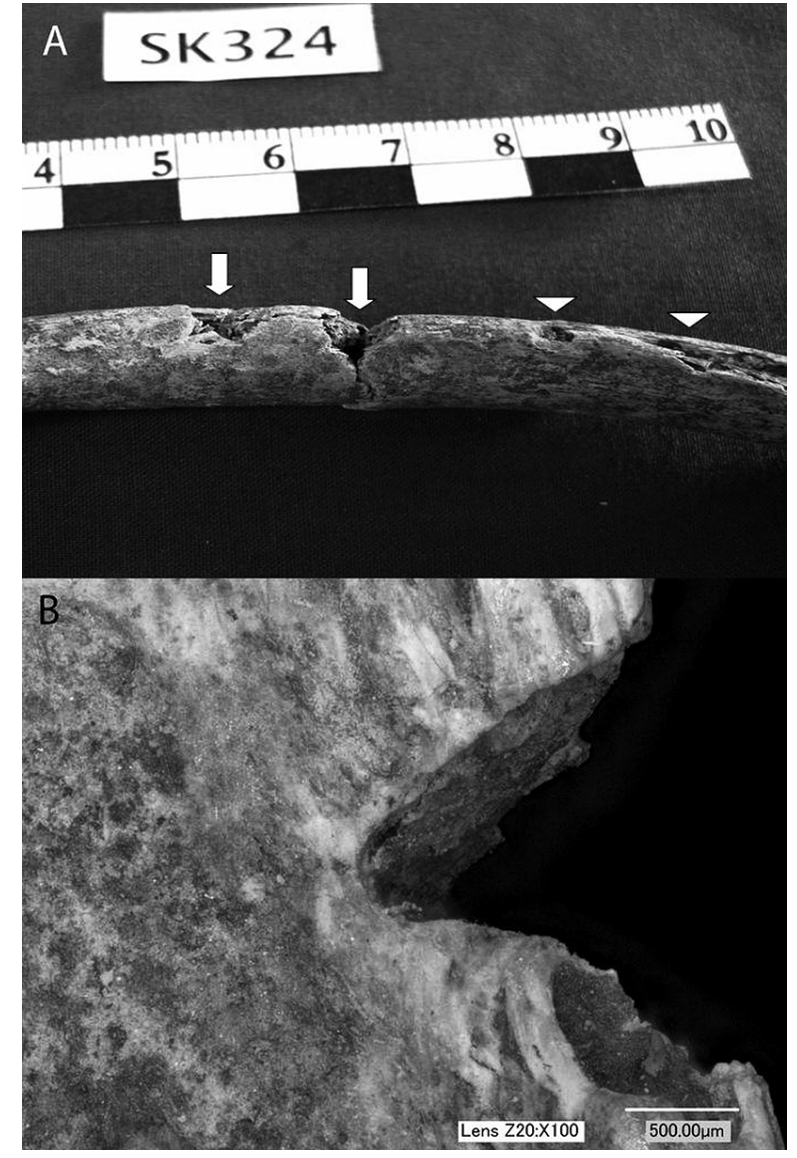

Figure 3. (A) Typical rib fragment (SK0324) displaying potential perimortem lesions observed in the Smith's Knoll collection. Evident on this fragment are two potential lesions (arrows) in addition to postmortem damage (arrowheads), indicating the need for cautious interpretation of the skeletal injuries observed. (B) A perimortem sharp force lesion on rib fragment SK0327 under the digital microscope. Despite the complicated mix of different types of damage present on the rib fragments, perimortem and postmortem lesions were much more easily distinguishable using the microscope. This lesion displays the triangular profile and sharp edges typical of perimortem injuries in the Smith's Knoll ribs. Magnification $\times 100$.

present on a fibula (SK0129) and multiple rib fragments following the evaluation of sharp force trauma in the collection. The association of the individuals in the Smith's Knoll assemblage with a battle context involving violent injury and death makes this site ideal for the examination of violence in the past, for which sharp force trauma in the skeleton is an important line of evidence.

Using osteological and experimental evidence, this paper will assess two simple questions that have the potential to contribute to our understanding of events that occurred on the battlefield. Thirty-eight lesions observed in the ribs displayed potentially perimortem characteristics, but extensive postmortem disturbance of the remains necessitates careful evaluation to differentiate perimortem injuries from taphonomic damage (Figure 3 ). The type of weapon likely responsible for inflicting the injury present on fibula fragment SK0129 is also investigated. Possible scenarios that could have resulted in the lesion observed on the fibula are evaluated in 
order to determine what this injury can tell us about soldier experience during the battle. This paper aims to expand the interpretations of sharp force injuries inflicted on the fibula and ribs at the battle of Stoney Creek.

\section{Materials and Methods}

\section{Background to the Smith's Knoll site}

The Smith's Knoll collection contains 2701 identifiable human bone fragments representing a minimum of 24 individuals. RGS Services excavated the assemblage in 1998 and 1999, and following brief analysis this was placed in storage containers within a stone monument at the battle site in 2000. Although reports are available on the excavation and original analysis of the bone fragments (McVeigh, 1998; Liston, 2000), it is not possible to extract clear information on possible damage that occurred during excavation given the lack of very detailed information and the period of time since the reports were written. The amount of information available regarding recovery of the remains is limited (Griffin-Short, 2000). During the current analysis undertaken in 2011 and 2012, the collection was catalogued in its entirety and basic information was recorded for each of the identifiable skeletal fragments. The original excavation reports do not contain detailed information regarding the provenience of skeletal fragments, and commingling in the assemblage is so severe that no fragments could be identified as belonging to the same individual. Each fragment had to be considered separately, and a unique number was assigned to each with the prefix SK. Completeness was assessed for each fragment using the zonation method, in which each element is split into defined zones based on common breakage points (Knüsel and Outram, 2004). Percent completeness was calculated by dividing the number of zones present for each fragment by the total number of possible zones for that element. The average completeness for elements in the sample is $47 \%$. Surface preservation was assessed by assigning a weathering grade to each fragment based on the stages set out by McKinley (2004). The fragments were assigned on average a grade of 2 , indicating more than just slight and patchy surface erosion, with some deeper surface penetration. All features evaluated for sex as set out by Buikstra and Ubelaker (1994) were consistent with all individuals in the collection being male. Age at death was assessed using epiphyseal fusion (Scheuer and Black, 2000) and the auricular surface (as set out in Buikstra and Ubelaker, 1994). Several age categories are represented, ranging from adolescent to middle adult as defined by Buikstra and Ubelaker (1994). The assemblage was analyzed for skeletal evidence of traumatic injury sustained during the battle with particular emphasis on lesions relating to perimortem fracture, sharp force trauma, and firearms injuries, all of which were observed in the collection.

\section{Assessment of sharp force trauma}

Perimortem sharp force lesions were identified based on characteristics such as sharp and straight edges, V-shaped injury profiles, hinging or lipping at lesion edges, and radiating fractures (Lovell, 2008). Postmortem damage displays rough and irregular edges and surfaces and a clear difference in color from the adjacent unaltered cortical surface. Postmortem lesions also lack clear injury profiles. For the ribs, perimortem injuries were identified based on sharp edges, a clear V-shaped profile, plastic deformation, and a lack of color difference between the lesion and surrounding surfaces (Table 1). The distinction between perimortem injuries and postmortem damage was only possible for lesions that had sufficient intact cortical bone to adequately examine the injury characteristics. Injuries identified as perimortem therefore had an intact cortex and at least two of the above perimortem injury characteristics.

Although the lesion on fibula fragment SK0129 could be identified as sharp force trauma, it was unclear in the absence of comparative lesions what type of bladed weapon may have caused the injury. Controlled clinical or forensic studies can be used to provide comparative images or samples for sharp force injuries. However, these typically utilize modern instruments and may have limited applicability to injuries inflicted by historical weaponry. Experimentally replicating the lesion observed on the fibula (SK0129) from the Smith's Knoll collection therefore allows examination of the potential origin of this injury, in order to gain information regarding the fighting conditions experienced by soldiers during the battle of Stoney Creek. Experimental lesions were also created on faunal ribs to replicate sharp force injuries to the thorax and assist in differentiating perimortem and postmortem damage on the Smith's Knoll ribs. While several other sharp force lesions were observed in the collection, these experimental analyses focused only on lesions in the fibula and ribs surrounding which significant questions remained.

\section{Production of comparative samples}

All experimental work was completed at Fort George in Niagara-on-the-Lake, Ontario, Canada, a War of 1812 fort maintained by Parks Canada and restored as a historical site. A range of replica weapons used for educational demonstrations was available including bayonets, several models of sword, and muskets (Figure 2). These replicate the original weapons used during the War of 1812 exactly in shape, size, and material. Based on historical accounts of the battle of Stoney Creek, these are the types of weapon that were likely present at the battle (Fredriksen, 1984, 1989; Merritt and Sutherland, 2001; Kaufman, 2003). The range and type of possible injuries that could be inflicted with the sword and bayonet on the battlefield have the potential to display considerable variability. This analysis focused on the scenarios most likely to have caused the specific injury observed in fibula fragment SK0129.

In order to test two simple injury scenarios for the lower leg, faunal proxies were chosen to represent the human tibia and fibula. Deer tibiae were found to approximate the size and shape of human tibiae, and lamb tibiae were found to approximate human fibulae most closely in diameter and cortical thickness and were considered most likely to produce comparable lesions on the cortical surface. Four lower leg replicas were constructed using one fresh defleshed deer tibia and one fresh defleshed lamb tibia for each, with foam earplugs and blue sticky tack placed between them at points of articulation to create an interosseous space. The bones 
Table 1. Classification of potential sharp force injuries in rib fragments

\begin{tabular}{|c|c|c|c|c|c|c|c|c|}
\hline Rib fragment & Side & $\begin{array}{c}\text { Percent } \\
\text { completeness }\end{array}$ & $\begin{array}{l}\text { Intact } \\
\text { cortex }\end{array}$ & $\begin{array}{c}\text { Color } \\
\text { difference }\end{array}$ & $\begin{array}{l}\text { Sharp } \\
\text { edges }\end{array}$ & $\begin{array}{c}\text { Plastic } \\
\text { deformation }\end{array}$ & $\begin{array}{l}\text { V-shaped } \\
\text { profile }\end{array}$ & Classification \\
\hline SK0324 & $\mathrm{L}$ & 100 & $\mathrm{P}$ & $P$ & $\mathrm{P}$ & A & $\mathrm{P}$ & PR \\
\hline SK0327 & $\mathrm{R}$ & 67 & $\mathrm{P}$ & A & $\mathrm{P}$ & A & $\mathrm{P}$ & PR \\
\hline SK0329 & $\mathrm{R}$ & 100 & $\mathrm{P}$ & $\mathrm{P}$ & $\mathrm{P}$ & $\mathrm{P}$ & $\mathrm{P}$ & PR \\
\hline SK0335 & $\mathrm{L}$ & 67 & $\mathrm{P}$ & A & $\mathrm{P}$ & $\mathrm{A}$ & $P$ & PR \\
\hline SK0336 & $\mathrm{L}$ & 67 & $\mathrm{P}$ & A & $\mathrm{P}$ & A & $\mathrm{P}$ & PR \\
\hline SK0338 & $\mathrm{L}$ & 67 & $\mathrm{P}$ & $\mathrm{P}$ & $\mathrm{P}$ & $\mathrm{A}$ & $\mathrm{P}$ & PR \\
\hline SK0339 & $\mathrm{R}$ & 67 & $\mathrm{P}$ & $\mathrm{P}$ & $\mathrm{P}$ & A & $\mathrm{P}$ & PR \\
\hline SK0340 & $?$ & 33 & $\mathrm{P}$ & $\mathrm{P}$ & $\mathrm{P}$ & A & $\mathrm{P}$ & PR \\
\hline SK0345 & $\mathrm{L}$ & 67 & $\mathrm{P}$ & $\mathrm{P}$ & $\mathrm{P}$ & A & $\mathrm{P}$ & PR \\
\hline SK0346 & $?$ & 33 & $\mathrm{P}$ & $\mathrm{P}$ & $\mathrm{A}$ & A & A & PS \\
\hline SK0351 & $\mathrm{L}$ & 67 & A & $\mathrm{P}$ & A & A & A & PS \\
\hline SK0362 & $?$ & 33 & $\mathrm{P}$ & $\mathrm{P}$ & A & A & A & PS \\
\hline SK0365 & $\mathrm{R}$ & 67 & $\mathrm{P}$ & $\mathrm{P}$ & A & $\mathrm{P}$ & $\mathrm{A}$ & PS \\
\hline SK0368 & $?$ & 33 & A & $\mathrm{P}$ & A & A & $\mathrm{A}$ & PS \\
\hline SK0369 & $\mathrm{L}$ & 67 & $\mathrm{P}$ & $\mathrm{P}$ & A & A & $\mathrm{A}$ & PS \\
\hline SK0370 & $\mathrm{L}$ & 67 & $\mathrm{P}$ & A & $\mathrm{P}$ & $\mathrm{A}$ & $\mathrm{P}$ & PR \\
\hline SK0371 & $\mathrm{L}$ & 67 & $\mathrm{P}$ & $\mathrm{P}$ & $\mathrm{P}$ & A & $\mathrm{P}$ & PR \\
\hline SK0383 & $\mathrm{L} ?$ & 67 & $\mathrm{P}$ & $\mathrm{P}$ & A & A & $\mathrm{A}$ & PS \\
\hline SK0418 & $\mathrm{L}$ & 100 & A & $\mathrm{P}$ & A & A & A & PS \\
\hline SK0437 & $?$ & 33 & $\mathrm{P}$ & $\mathrm{P}$ & A & A & A & PS \\
\hline SK0442 & $\mathrm{L} ?$ & 33 & $\mathrm{P}$ & $\mathrm{P}$ & A & A & A & PS \\
\hline SK0448 & $?$ & 33 & $\mathrm{P}$ & $\mathrm{P}$ & A & A & A & PS \\
\hline SK0452 & $?$ & 33 & $\mathrm{P}$ & A & A & A & A & PS \\
\hline SK0473 & L? & 33 & $\mathrm{P}$ & A & A & A & A & PS \\
\hline SK0488 & $?$ & 33 & $\mathrm{P}$ & A & A & A & A & PS \\
\hline SK0508 & $?$ & 33 & $\mathrm{P}$ & $P$ & A & A & A & PS \\
\hline SK0539 & ? & 33 & $\mathrm{P}$ & $\mathrm{P}$ & A & A & A & PS \\
\hline SK0558 & $\mathrm{L} ?$ & 67 & $\mathrm{P}$ & A & A & A & A & PS \\
\hline SK0636 & ? & 33 & A & $\mathrm{P}$ & A & A & A & PS \\
\hline SK0708 & L? & 33 & $\mathrm{P}$ & $\mathrm{P}$ & A & $\mathrm{P}$ & $\mathrm{P}$ & PR \\
\hline SK0715 & ? & 67 & A & $\mathrm{P}$ & A & A & A & PS \\
\hline SK0739 & L & 67 & $\mathrm{P}$ & $\mathrm{P}$ & A & A & A & PS \\
\hline SK0748 & $\mathrm{R}$ ? & 33 & $\mathrm{P}$ & $\mathrm{P}$ & A & A & A & PS \\
\hline SK0757 & $?$ & 33 & $\mathrm{P}$ & $\mathrm{P}$ & A & $\mathrm{P}$ & A & PS \\
\hline SK0766 & $\mathrm{L}$ & 100 & $\mathrm{P}$ & $\mathrm{P}$ & A & A & A & PS \\
\hline SK0788 & $\mathrm{R}$ & 67 & $\mathrm{P}$ & $\mathrm{P}$ & A & A & A & PS \\
\hline SK0792 & $\mathrm{R}$ ? & 67 & $\mathrm{P}$ & A & $\mathrm{P}$ & $\mathrm{P}$ & $\mathrm{P}$ & PR \\
\hline SK0802 & $?$ & 33 & $\mathrm{P}$ & $\mathrm{P}$ & $\mathrm{P}$ & A & $\mathrm{P}$ & PR \\
\hline
\end{tabular}

Abbreviations: R, right; L, left; ?, unknown; R?, potentially right; L?, potentially left; P, present; A, absent; PR, perimortem; PS, postmortem.

were secured tightly together using large elastic bands (Figure 4). No attempt was made to replicate soft tissues as very little soft tissue covers the anteromedial aspect of the lower leg, where the injury under investigation is located. Although factors such as retraction of tendons in a living person will influence the impact of a blade on bone, accounting for this is not possible with faunal proxies. In terms of clothing, the most significant potential impact on sharp force injury would relate to the wearing of leather boots. Most regular infantry in both the British and American armies wore shoes rather than boots, and these would not have impacted on the site of injury located approximately $15 \mathrm{~cm}$ above the base of the heel. The small sample size of four replica legs, dictated by the difficulty of accessing experimental materials, limited the number of factors within each scenario for which variation could be considered, and therefore allows only general conclusions to be made about the circumstances surrounding the infliction of the injury to the fibula.

Each replica leg was affixed to a bale of hay, providing sufficient support to immobilize the elements without im- parting unnatural rigidity. Each leg was struck in such a way as to test two potential injury scenarios, with a male staff member from Fort George handling all weapons to better approximate the amount of force behind injuries occurring in a battle situation. The first injury scenario suggests that a sword sliced through the tibia and impacted the anteromedial aspect of the distal fibula at the end of its stroke, and the second that a bayonet penetrated the interosseous space between the tibia and fibula and impacted the fibula on the anteromedial surface (Figure 5). Samples 1 and 2 were oriented on the hay with the deer tibia located superior to the lamb tibia, and then struck with a sword so that the blade passed through the 'tibia' before impacting the 'fibula.' Samples 3 and 4 were stabbed with a bayonet so that the triangular tip was thrust into the interosseous space and impacted both the 'tibia' and the 'fibula.' The bones of samples 3 and 4 were tied together with string, since the elastic bands were unable to secure them well enough to prevent them from moving apart under the force of the bayonet thrust. The string provided additional stability, 


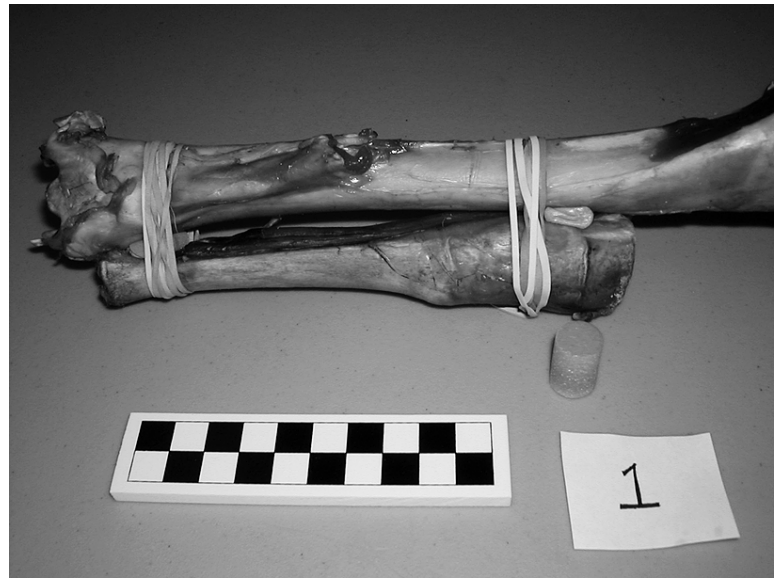

Figure 4. Experimental leg 1, showing how the replica lower legs were constructed. The deer tibia (replica human tibia) is positioned above the lamb tibia (replica human fibula). The two are secured together with elastic bands, and correctly spaced with sticky tack and earplugs.

approximating the limitations to lateral mobility imposed by normal human anatomy in the lower leg. All leg injuries were inflicted using a single blow.

The triangular socket bayonet was also used to create comparative lesions in faunal ribs in order to establish more securely whether the lesions observed in the archaeological material could be classified as perimortem. As pig bones are generally considered to be an acceptable proxy for human bones (Wieberg and Wescott, 2008), a rack of pork side ribs (approximately $15 \mathrm{~cm}$ long, from the sternal end) with all of the meat covering the bones was chosen to replicate the human torso. The ribs were affixed to the hay bale, and the bayonet was thrust into the ribs several times by a male Fort George employee to impact and create lesions in as many ribs as possible.

The replica legs and ribs were processed in the laboratory. The bones were placed in a large pot filled with water and allowed to simmer for 5-6 hours to facilitate the removal of soft tissues, particularly from the ribs. The small amounts of adhering soft tissue were then manually removed. Any bones that did not show evidence of sharp force impacts were discarded prior to further processing. The remaining elements were placed in square plastic-lidded containers with 10-10.5 grams of Tergazyme biological detergent (Mairs et al., 2004) and enough water to completely cover the bone. Each sample was incubated at $47^{\circ}$ Centigrade for approximately two weeks, with the water changed as necessary every few days. Processing was considered complete when all soft tissue and bone marrow had been removed from the bones. The elements were then rinsed and allowed to dry completely at room temperature.

Detailed photographs of the lesions in experimental and archaeological elements were taken using a VHX-1000E digital microscope at magnifications of 20,30, and 50 times. Additionally, the descriptions of the diagnostic characteristics of sword injuries provided by Lewis (2008) were used to evaluate the potential etiology of the lesion observed on fibula fragment SK0129.

\section{Results}

\section{Lower leg lesion}

Some experimental lesions in the replica lower legs were clearer than others following processing (Table 2). In both
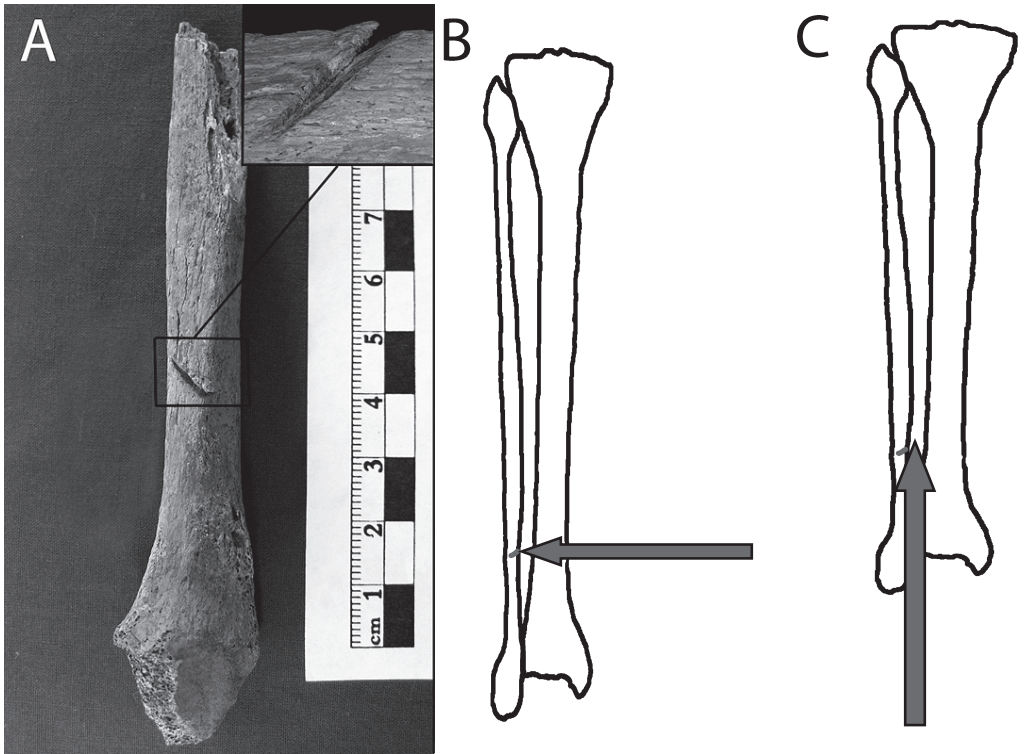

Figure 5. (A) Fragment SK0129, showing the position of the potential perimortem lesion. Inset: image of the lesion under the digital microscope at a magnification of $\times 30$, in a profile view, highlighting the sharp and straight lower edge and deformed upper edge of the cut mark. (B) The first posited scenario: the lesion results from a sword that cut through the tibia from the medial side to impact the anteromedial surface of the fibula. (C) The second posited scenario: the lesion results from a bayonet that was thrust in from the anterior direction to impact the anteromedial surface of the fibula. 
Table 2. Lesion characteristics of experimental and archaeological sharp-force injuries to the lower leg

\begin{tabular}{|c|c|c|c|c|c|c|c|}
\hline \multirow{2}{*}{ Specimen } & \multirow{2}{*}{ Weapon } & \multirow{2}{*}{$\begin{array}{c}\text { Observable } \\
\text { fibula } \\
\text { lesions }\end{array}$} & \multirow{2}{*}{$\begin{array}{c}\text { Observable } \\
\text { tibia } \\
\text { lesions }\end{array}$} & \multicolumn{3}{|c|}{ Lesion Characteristics-fibula } & \multirow{2}{*}{ Lesion Characteristics-tibia } \\
\hline & & & & Profile shape & Top edge & Bottom edge & \\
\hline Leg 1 & sword & 0 & 1 & - & - & - & cleanly sliced through \\
\hline Leg 2 & sword & 1 & 1 & unclear & rough & rough & cleanly sliced through \\
\hline Leg 3 & bayonet & 1 & 1 & $\begin{array}{l}\text { V-shaped with one } \\
\text { smooth and one rough } \\
\text { side }\end{array}$ & $\begin{array}{l}\text { plastic } \\
\text { deformation }\end{array}$ & rough & $\begin{array}{l}\text { Slight V-shaped lesion } \\
\text { otherwise resembling leg } 3 \\
\text { fibula lesion }\end{array}$ \\
\hline $\operatorname{Leg} 4$ & bayonet & 1 & 0 & $\begin{array}{l}\text { shallow U-shape, lost in } \\
\text { processing }\end{array}$ & $\begin{array}{l}\text { unclear, } \\
\text { no sharp edge }\end{array}$ & $\begin{array}{l}\text { unclear, } \\
\text { no sharp edge }\end{array}$ & - \\
\hline SK0129 & unknown & 1 & 1 & $\begin{array}{l}\text { acute angled wall and } \\
\text { obtuse angled wall }\end{array}$ & $\begin{array}{l}\text { plastic } \\
\text { deformation }\end{array}$ & straight kerf & - \\
\hline $\begin{array}{l}\text { Lewis } \\
(2009)\end{array}$ & sword & NR & NR & $\begin{array}{l}\text { acute angled wall and } \\
\text { obtuse angled wall }\end{array}$ & $\begin{array}{l}\text { plastic } \\
\text { deformation }\end{array}$ & straight kerf & NR \\
\hline
\end{tabular}

—, no lesions observed; NR, no data reported.

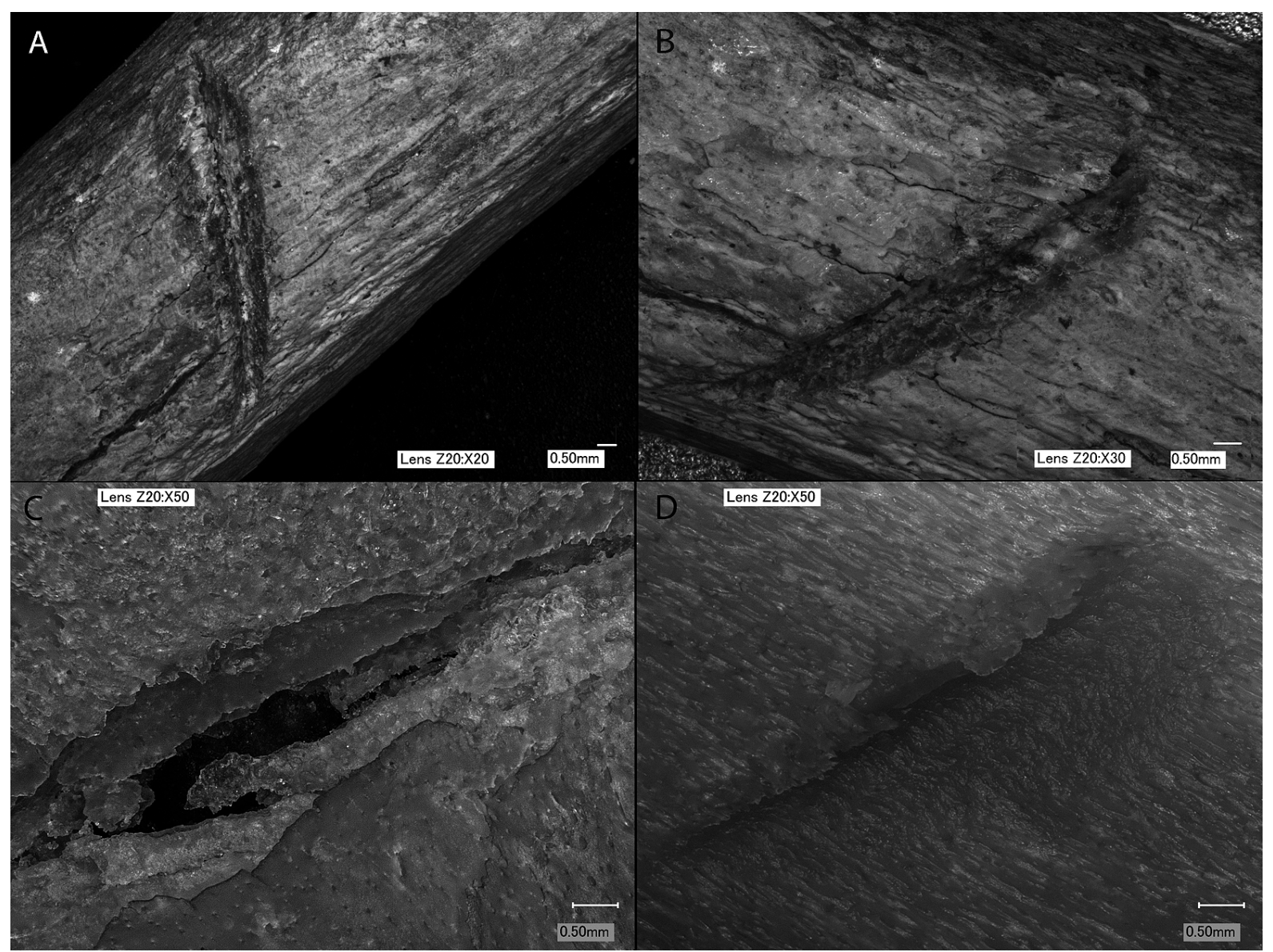

Figure 6. (A) The potential perimortem sharp force lesion on fibula fragment SK0129 under the digital microscope at a magnification of $\times 20$. This clearly shows the lipping at one edge of the lesion, and the small associated radiating fracture. (B) The lesion on SK0129 under the digital microscope at the higher magnification of $\times 30$. This more clearly shows the sharply cut smooth edge of the lesion. (C) The lesion on experimental leg 2, produced using the replica sword, under the digital microscope. Magnification $\times 50$. (D) The lesion on experimental leg 3 , produced using the replica bayonet, under the digital microscope. This lesion differs in appearance from the archaeological lesion on SK0129 (in B). Magnification $\times 50$.

replica legs impacted with a sword, the blade easily sliced through the 'tibia' to impact the 'fibula.' This indicates that the first proposed scenario could have caused the lesion observed on SK0129. Experimental sample 1 displayed an observable lesion on the 'fibula' in the field, but following processing there were no clear lesions on the diaphysis. It is possible that the lesion observed prior to processing failed to impact any deeper than the periosteum, and was lost when the periosteum was removed. Sample 2 also did not show a clear-cut mark on the diaphysis of the 'fibula.' There was a perimortem defect near the distal end of the shaft, but it had the appearance of a depressed fracture with some sharp 


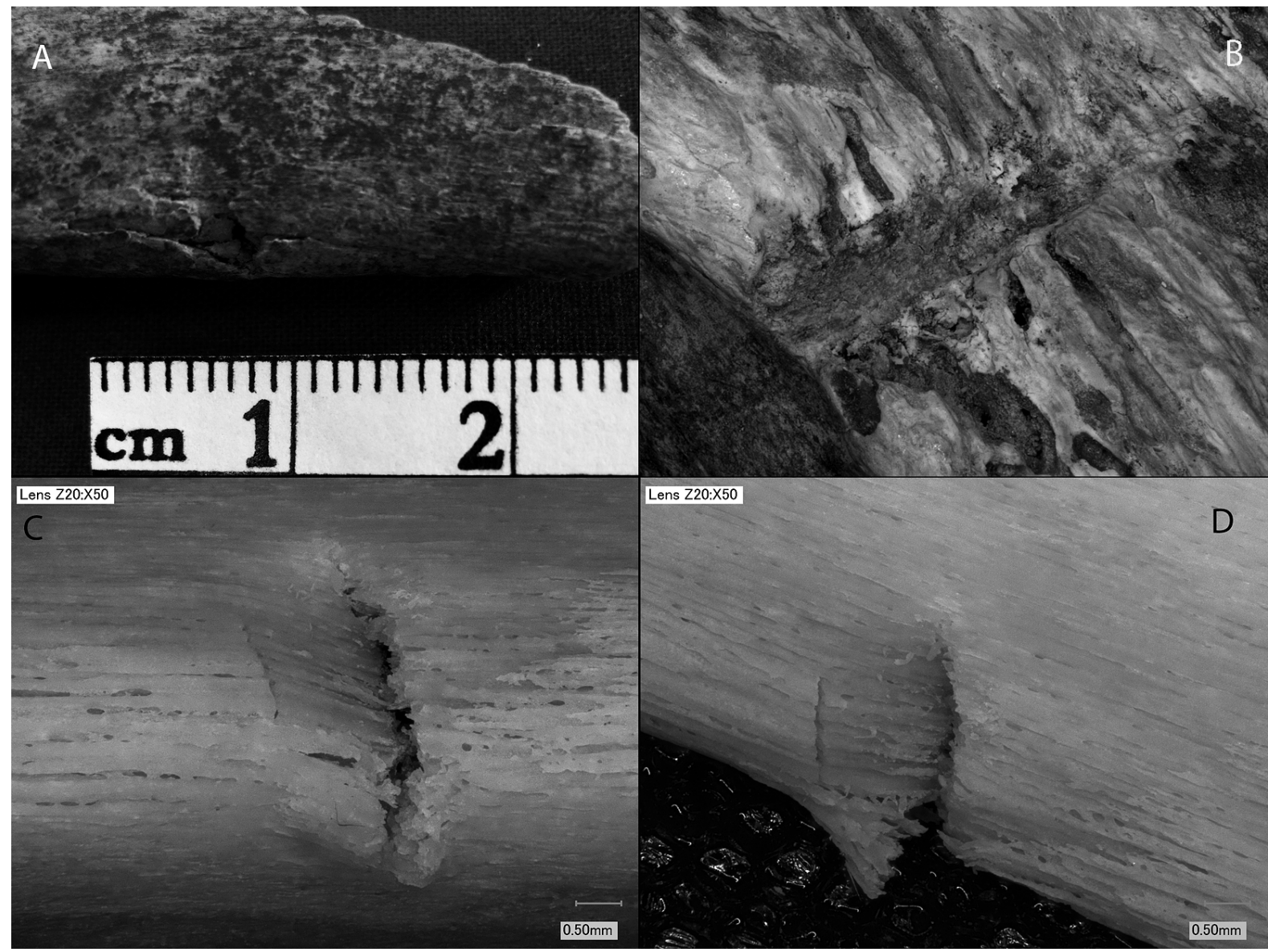

Figure 7. (A) The potential perimortem sharp force lesion on rib fragment SK0708, a lesion typical of those observed in the rib fragments of the collection. (B) The potential perimortem sharp force lesion along the caudal edge of rib fragment, SK0327, under the digital microscope. This clearly shows the sharply sliced edge displayed by many of the rib lesions observed in the collection. Magnification $\times 50$. (C, D) Two views of the experimentally produced lesion on experimental rib 1 . This lesion was created using a replica bayonet. Magnifications $\times 50$.

characteristics rather than a sharp cut mark (Figure 6).

Much clearer comparative lesions were observed on the two samples impacted with the bayonet. Sample 3 displayed clear lesions on both the 'tibia' and the 'fibula' (Figure 6). Sample 4 also displayed cut marks on the 'tibia' and 'fibula,' but these were fairly shallow. The outer cortical surface of this specimen peeled during processing, as the result of a bad reaction to the detergent used. Damage to the cortical surface prevented effective observation of the lesions produced on this sample.

\section{Rib lesions}

Clear lesions were displayed on several of the pig ribs impacted with the triangular socket bayonet, consisting mainly of triangular nicks along the cranial and caudal edges (Figure 7; Table 3). The rib lesions created using the bayonet differ in appearance from the fibula lesions created using the same weapon (Figure 6D) as a result of differences in the characteristics of these two elements, illustrating the importance of creating separate experimental samples for comparison with archaeological injuries to different elements. The experimental rib lesions are similar in appearance to several of the injuries observed on archaeological rib fragments
Table 3. Lesion characteristics of experimental bayonet injuries to the ribs

\begin{tabular}{|c|c|c|c|}
\hline \multirow{2}{*}{ Specimen } & \multicolumn{3}{|c|}{ Lesion characteristics } \\
\hline & Location & Profile shape & Other features \\
\hline Rib 1 & cranial edge & V-shaped & $\begin{array}{l}\text { plastic deformation, no } \\
\text { sharp edge }\end{array}$ \\
\hline Rib 2 & cranial edge & V-shaped & very sharp edge \\
\hline Rib 3 & anterior side & V-shaped & $\begin{array}{l}\text { radiating fractures } \\
\text { (at edges) }\end{array}$ \\
\hline Rib 4 & mid-shaft & - & $\begin{array}{l}\text { fractured segments } \\
\text { separated }\end{array}$ \\
\hline Rib 5 & mid-shaft & - & $\begin{array}{l}\text { fractured segments } \\
\text { separated }\end{array}$ \\
\hline
\end{tabular}

This table contains information regarding only the five ribs that showed lesions; the seven ribs without observable lesions were discarded.

from the Smith's Knoll sample. Based on correspondence with the experimental lesions and the identification of sharp margins, plastic deformation, lack of a difference in color between the lesion and surrounding cortex, and clear Vshaped profiles, 14 of the 38 rib lesions were classified as 
perimortem (Table 1). Lesions for which insufficient cortical surface was preserved to observe perimortem lesion characteristics were classified as postmortem.

\section{Discussion}

The experimental lesions created on replica ribs and lower legs provided comparative material, indicating the likely variation in appearance and, for the fibula, the potential cause of perimortem lesions observed within the Smith's Knoll sample. Marks created on the replica ribs provided excellent comparative lesions, allowing many of the injuries seen in the archaeological rib fragments to be identified as perimortem sharp force trauma. Following burial of the remains, the Smith's Knoll site underwent continued use as a farm and later on as a construction site (Griffin-Short, 2000). Given this history of land use at the site, other marks on the ribs likely result from taphonomic damage related to impacts from farming implements or shovels that can mimic sharp force injuries. Lesions created in the replica legs allowed evaluation of the cut mark observed on the distal fibular fragment SK0129, and provided evidence suggesting the injury was likely caused by a sword stroke.

The perimortem lesion on fibula fragment SK0129 is a sharp cut mark on the distal anteromedial surface of the diaphysis. Based on comparison with the experimental lesions on leg number 3, this injury differs in appearance from a lesion produced by a bayonet. The lesion observed in the archaeological material displays a very sharp and straight lower edge, with a slightly hinged upper edge that is lipped away from the sharp kerf floor (Figure 6). There is a small radiating fracture associated with the lesion, representing the blunt force aspect of the impact and providing support for this injury as being a result of the end of a large, powerful stroke. While there are some similarities between the experimental bayonet injury and the lesion observed on SK0129, including the deformed appearance of the upper edge of the lesion, there are several important differences. The bayonetinduced injury is much shallower than the archaeological lesion (Table 2), does not show the very sharp and smoothly sliced lower edge, and has no associated fracturing (Figure 6D). This injury is not likely to have been caused by the impact of a bayonet.

It is difficult to definitively identify the lesion on the distal fibula (SK0129) as a sword injury, given the lack of clear comparative lesions in the two replica legs impacted using the cavalry sword. However, the cut mark found on SK0129 is similar in many respects to the description of a characteristic sword lesion given by Lewis (2008) based on his own experimental work. The mark presents as a deep cut with a straight kerf, cross-sectionally displaying one obtuse angled wall and one acute angled wall with traces of damage rather than the consistent V-shape associated with a knife-like weapon. These traits are associated with damage caused by the sword rather than other classes of bladed weapon (Lewis, 2008: 2004). Sword marks, as described in the literature, generally display features associated with both the sharp cutting blade and some aspects of blunt force trauma such as lateral pushing back and radiating fractures, both of which are present on fragment SK0129. Very few bayonet injuries have been described in the lower limbs, and these appear to be in the form of chip fractures (Rose et al., 1988). The appearance of the bayonet lesion identified by Rose et al. (1988) radiographically in clinical material differs significantly from the lesion observed in this collection. More specific information regarding the characteristics of the lesion on SK0129 could be accessed through scanning electron microscope (SEM) analysis of a cast of this lesion. However, the process required to cast the lesion using dental impression material caused too much damage to the exterior surface of the fragile and poorly preserved remains. Interpretation of the injury therefore relied upon features visible using macroscopic and light microscopic examination, and any information on lesion cause solely accessible through SEM analysis of striations on the kerf of the lesion was unavailable.

Based on the evidence available regarding positioning and injury characteristics, it appears likely that the lesion observed on SK0129 resulted from the cutting impact of a sword stroke rather than the stabbing impact of a socket bayonet. This suggests that the first scenario, in which a sword cut through the tibia and impacted the fibula at the end of its stroke, is more likely to have caused this injury. However, in the absence of a clear comparative experimental lesion resulting from a sword impact, this association can be made solely based on the descriptive evidence provided by Lewis (2008). No fragments of tibia with evidence of sharp force characteristics were observed in the collection to provide added support for the above scenario; it is likely that any such evidence that may have existed has been masked by postmortem alteration of the remains. All that can be securely concluded is that the injury observed on SK0129 does not resemble the lesions created with the thrust of a bayonet and does not seem to have been produced by the mechanism of injury associated with the socket bayonet.

The conclusions that can be made beyond suggesting that the injury to the fibula was likely associated with a sword blow that sliced through the tibia prior to impacting the fibula are limited. This lesion may have been inflicted from various sides and angles depending on the position of the two individuals. It cannot be established that the injured individual was in a standing position. While the depth and blunt force characteristics of the injury suggest that the leg was relatively well stabilized at the time of impact, this stability could be gained not only by planting the foot on the ground by also by lying with the leg against the ground. The dark, confusing, and chaotic conditions that prevailed during the battle of Stoney Creek make either of these positions, and therefore a diverse range of injury scenarios, equally possible.

The positioning of the rib and lower leg injuries is unusual based on what is known about typical battle strategy and conditions during the War of 1812 (Kaufman, 2003). These lesions are also quite different from injuries observed at other roughly contemporaneous battle sites. Skeletal material from another War of 1812 site in southern Ontario, Snake Hill, displays a high prevalence of perimortem injuries distributed throughout the skeleton, with the highest percentage of fractures in the ribs and fractures additionally observed in elements of the upper and lower extremities (Owsley et al., 
1991). However, these injuries are referred to simply as fractures, and while the authors state that several of the lesions were consistent in appearance with projectile injuries, no mention is made of any sharp force characteristics (Owsley et al., 1991). Sharp force lesions were observed in skeletal material from the battle of the Little Bighorn, in several elements of the upper and lower extremities although not in the lower leg. However, based on historical information about the battle, this sharp force trauma relates entirely to injuries inflicted with tomahawks, and is discussed mainly in the context of postmortem mutilation and dismemberment rather than possible close-range fighting as at Smith's Knoll (Scott et al., 1998). Many examples of perimortem injury to the lower leg are present in the Ballingall museum collection, which consists of the remains of soldiers who were injured and underwent surgical treatment during British military conflicts in the first half of the 19th century (Kaufman, 2003). All lesions in the lower limbs observed in this collection, however, relate to musket trauma rather than sharp force injury. It therefore appears that while musket injuries to the lower limb were relatively commonly experienced in battle contexts during this time period, sharp force injuries to the lower limb are rarely described. Given the absence of any documented sword or bayonet injuries in skeletal material from contemporary archaeological sites, there are no cut marks with which those observed at Smith's Knoll can be compared.

Perimortem injury to the ribs in the form of fractures or musket trauma has been commonly observed in battlerelated archaeological and surgical collections from this time period. However, rib lesions specifically identified as having been caused by bladed weapons such as swords or bayonets have not been identified at other contemporaneous archaeological sites (e.g. Snow and Fitzpatrick, 1989; Owsley et al., 1991; Scott et al., 1998), and have only rarely been observed in historical surgical collections (Kaufman, 2003). In the ribs, the presence of so many sharp force lesions runs counter to the fact that these weapons most efficiently inflicted injuries in softer and less skeletally complex areas of the body such as the abdomen, where the bayonet ran less chance of becoming stuck in the bone and difficult to extricate. British soldiers were typically given very little training in the use of the bayonet (Kaufman, 2003), and likely had minimal experience in actually using these weapons. The American army similarly lacked an official manual for training in the use of the bayonet until 1852 (McClellan, 1852). It is likely that the occurrence of lesions reflecting the inefficient use of available sharp force weapons may be related to a lack of proper training combined with the unique battle conditions present at Stoney Creek. Occurring at night, the fighting during this battle was confused and chaotic (Fredriksen, 1984, 1989; Merritt and Sutherland, 2001). The atypical close-range combat that occurred here made typical battle strategy difficult to follow. Given inaccuracies in the aim and performance of the smoothbore musket designed to be fired at a line of soldiers, the lack of massed infantry formations at Stoney Creek would have decreased soldiers' ability to effectively use their muskets and increased their reliance on swords and bayonets, designed for use at closer ranges (Kaufman, 2003). Soldiers who had undergone only minimal training in the use of these weapons, and had little occasion to gain experience using them in combat, would be less likely to handle them with maximum efficiency under unusual and stressful battle conditions. The observation of unusual injuries such as sword wounds in the lower limbs and sharp force injuries in the thorax therefore corresponds well with what is known about battle conditions experienced by the individuals in the Smith's Knoll collection. These lesions serve as an example providing supporting evidence for the information present in historical accounts of the battle of Stoney Creek. However, further contextualization of this information in terms of sharp force injuries experienced during other battles of this period is precluded by the fact that no archaeological examples of sharp force injuries from contemporaneous sites have yet been described.

\section{Conclusion}

The appearance of experimentally generated sword and bayonet lesions on faunal proxies for the human ribs and lower legs provided additional evidence allowing a more secure evaluation of the origin or potential cause of several sharp force lesions in the Smith's Knoll collection. Comparison with experimental sword- and bayonet-inflicted injuries as well as with injury characteristics described by Lewis (2008) allowed the identification of a likely sword-induced injury to the distal fibula, as well as the association of 14 of the lesions observed in the ribs with a perimortem origin. The presence of primary and secondary historical sources regarding soldier experience during the battle of Stoney Creek creates a unique opportunity to contextualize more richly the information provided by the skeletal record. Linking skeletal evidence for sharp force trauma with historical information on the weapons used and conditions experienced during the battle of Stoney Creek contributes to a truly bioarchaeological examination of violence in the past.

\section{Acknowledgments}

The authors would like to thank the City of Hamilton, Planning and Economic Development Department, Tourism and Culture Division, for providing the funding for the reanalysis of the Smith's Knoll skeletal collection. Many thanks go to the staff at Fort George for their provision of the location and replica weaponry, as well as for their assistance in carrying out experimental procedures. We would like to thank the staff of the meat department at the Main Street West Fortino's in Hamilton, ON for their generous donation of the lamb tibiae used. Thanks also to Kandace Bogaert for acquiring the deer tibiae used during this experiment and to Lori D'Ortenzio for her assistance with acquiring necessary materials and transportation. Thank you to Keyence Corporation for the loan of the digital microscope used to complete the microscopic analyses. Finally, we are grateful to Ron Dale, the War of 1812 Bicentennial Project Manager with Parks Canada, who provided suggestions and insight regarding possible injury scenarios. 


\section{References}

Alunni-Perret V., Muller-Bolla M., Laugier J.P., Lupi-Pégurier L., Bertrand M.F., Staccini P., Bolla M., and Quatrehomme G. (2005) Scanning electron microscopy analysis of experimental bone hacking trauma. Journal of Forensic Science, 50: 796-801.

Alunni-Perret V., Borg C., Laugier J.P., Bertrand M.F., Staccini P., Bolla M., Quatrehome G., and Muller-Bolla M. (2010) Scanning electron microscopy analysis of experimental bone hacking trauma of the mandible. American Journal of Forensic Medical Pathology, 31: 326-329.

Buikstra J.E. and Ubelaker D.H. (eds.) (1994) Standards for Data Collection From Human Skeletal Remains. Arkansas Archaeological Survey Research Series No. 44. Arkansas Archaeological Society, Fayetteville.

Elliott J.E. (2009) Strange Fatality: The Battle of Stoney Creek, 1813. Robin Brass Studio, Toronto.

Fredriksen J.C. (1984) Memoirs of Captain Ephraim Shaler: a Connecticut Yankee in the War of 1812. New England Quarterly, 57: 411-420.

Fredriksen J.C. (1989) Colonel James Burn and the War of 1812: the letters of a South Carolina Officer. The South Carolina Historical Magazine, 90: 299-312.

Griffin-Short R (ed.). (2000) 1999 Field Work at Smith's Knoll Historic Cemetery for the City of Stoney Creek, Ontario. RGS Archaeological Services, Stoney Creek.

Humphrey J.H. and Hutchinson D.L. (2001) Macroscopic characteristics of hacking trauma. Journal of Forensic Science, 46: $228-233$

Kaufman M.H. (2003) Musket-ball and Sabre Injuries From the First Half of the Nineteenth Century. The Royal College of Surgeons of Edinburgh, Edinburgh.

Knüsel C. and Outram A.K. (2004) Fragmentation: the zonation method applied to fragmented human remains from archaeological and forensic contexts. Environmental Archaeology, 9: $85-97$.

Lewis J.E. (2008) Identifying sword marks on bone: criteria for distinguishing between cut marks made by different classes of bladed weapons. Journal of Archaeological Science, 35: 2001-2008.

Liston M. (2000) Smith's Knoll 1999 osteological report. In: Griffin-Short R. (ed.), 1999 Field Work at Smith's Knoll Historic Cemetery for the City of Stoney Creek, Ontario. RGS Archaeological Services, Stoney Creek, pp. 171-181.

Lockau L. (2012) Bioarchaeological analysis of trauma in a skeletal sample from Smith's Knoll historic cemetery. Unpublished Master of Arts thesis, McMaster University. Accessible at http://digitalcommons.mcmaster.ca/cgi/viewcontent.cgi? article $=8387 \&$ context $=$ opendissertations $\&$ sei-redir $=1 \&$ referer $=\mathrm{http} \% 3 \mathrm{~A} \% 2 \mathrm{~F} \% 2 \mathrm{Fscholar}$.google.ca $\% 2 \mathrm{Fscholar} \% 3 \mathrm{Fhl} \% 3$ Den\%26q\%3DLockau\%2Bbioarchaeology\%26btnG\%3D\% 26as_sdt $\% 3 \mathrm{D} 1 \% 252 \mathrm{C} 5 \% 26$ as_sdtp $\% 3 \mathrm{D} \#$ search $=\% 22$ Lockau $\% 20$ bioarchaeology $\% 22$

Lovell N.C. (2008) Analysis and interpretation of skeletal trauma. In Katzenberg M.A. and Saunders S.R. (eds.), Biological Anthropology of the Human Skeleton. Wiley-Liss, Hoboken, NJ, pp. 341-386.

Lynn K.S. and Fairgrieve S.I. (2009) Macroscopic analysis of axe and hatchet trauma in fleshed and defleshed mammalian long bones. Journal of Forensic Science, 54: 786-792.

Mairs S., Swift B., and Rutty G.N. (2004) Detergent: an alternative approach to traditional bone cleaning methods for forensic practice. American Journal of Forensic Medical Pathology, 25: 276-284.

McClellan G.B. (1852) Manual of Bayonet Exercise: Prepared for the Use of the Army of the United States. JB Lippincott \& Co., Philadelphia.

McKinley J.I. (2004). Compiling a skeletal inventory: disarticulated and commingled remains. In Brickley M. and McKinley J. (eds.), Guidelines to the Standards for Recording Human Remains. BABAO, Reading, pp. 14-17.

McVeigh C. (1998) Human bone report. In Griffin-Short R. (ed.), Report: Archaeological Assessment, Smith's Knoll Historic Cemetery. RGS Archaeological Services, Stoney Creek, pp. 1-13.

Merritt W.H. and Sutherland S. (2001) "A desire of serving and defending my country": The War of 1812 Journals of William Hamilton Merritt. Iser Publications, Toronto.

Novak S.A. (2000) Battle-related trauma. In Fiorato V., Boylston A. and Knüsel C. (eds.), Blood Red Roses. Oxbow Books, Oxford, pp. 90-102.

Ortner D.J. (2011) Human skeletal paleopathology. International Journal of Paleopathology, 1: 4-11.

Owsley D.W., Mann R.W., and Murphy S.P. (1991) Injuries, surgical care, and disease. In Pfeiffer S. and Williamson R.F. (eds.), Snake Hill: An Investigation of a Military Cemetery from the War of 1812. Dundurn Press, Toronto.

Rose S.C., Fujisaki C.K., and Moore E.E. (1988) Incomplete fractures associated with penetrating trauma: etiology, appearance, and natural history. Journal of Trauma, 28: 106-109.

Scheuer L. and Black S. (2000) Developmental Juvenile Osteology. Academic Press, San Diego.

Scott D.D. and McFeaters A.P. (2011) The archaeology of historic battlefields: a history and theoretical development in conflict archaeology. Journal of Archaeological Research, 19: 103132.

Scott D.D., Willey P., and Connor M.A. (1998) They Died with Custer: Soldiers' Bones from the Batle of the Little Bighorn. University of Oklahoma Press, Norman.

Shaw K.P., Chung J.H., Chung F.C., Tseng B.Y., Pan C.H., Yang K.T., and Yang C.P. (2011) A method for studying knife tool marks on bone. Journal of Forensic Science, 56: 967-971.

Smith O.C., Pope E.J., and Symes S.A. (2009) Look until you see: identification of trauma in skeletal material. In Steadman D.W. (ed.), Hard Evidence: Case Studies in Forensic Anthropology. Prentice Hall, Upper Saddle River, NJ, pp 138-154.

Snow C.C. and Fitzpatrick J. (1989) Human osteological remains from the battle of the Little Bighorn. In Scott D.D., Fox R.A., Connor M.A., and Harmon D. (eds.), Archaeological Perspectives on the Battle of the Little Bighorn. University of Oklahoma Press, Norman, pp. 243-282.

Turner W.B. (2000) The War of 1812: The War That Both Sides Won. The Dundurn Group, Toronto.

Wieberg D.A.M. and Wescott D.J. (2008) Estimating the timing of long bone fractures: correlation between the postmortem interval, bone moisture content, and blunt force trauma fracture characteristics. Journal of Forensic Science, 53: 10281034. 